\title{
Influence of Processing Techniques on Microhardness and Impact Strength of Conventional and Reinforced Heat Cured Acrylic Resin: A Comparative Study
}

\author{
AISHA KIRAN ${ }^{1}$, FAIZA AMIN ${ }^{2}$, MUNEEB A LONE ${ }^{3 *}$, IMRAN ALAM MOHEET ${ }^{1}$, \\ MAHAM M LONE ${ }^{4}$, SYED MAHMOOD ${ }^{5}$, MUHAMMAD SOHAIL ZAFAR ${ }^{6,7^{*}}$ \\ ${ }^{1}$ Department of Science of Dental Materials, Baqai Dental College, Baqai Medical University, Karachi, Pakistan \\ ${ }^{2}$ Department of Science of Dental Materials, Dow University of Health Sciences, Karachi, Pakistan \\ ${ }^{3}$ Department of Prosthodontics, Dr Ishrat-ul-Ebad Khan Institute of Oral Health Sciences, Dow University of Health \\ Sciences, Karachi, Pakistan \\ ${ }^{4}$ Department of Operative Dentistry, Sindh Institute of Oral Health Sciences, Karachi, Pakistan \\ ${ }^{5}$ Scientific Officer, Plastic and Polymer Section, Pakistan Council of Scientific and Industrial Research (PCSIR) - Labs \\ complex, Karachi. Pakistan \\ ${ }^{6}$ Department of Restorative Dentistry, College of Dentistry, Taibah University, Al Madinah, Al Munawwarah, Saudi Arabia \\ ${ }^{7}$ Department of Dental Materials, Islamic International Dental College, Riphah International University, Islamabad, Pakistan
}

\begin{abstract}
This study determined and compared the influences of various processing techniques including air circulating oven (ACO), dry heat oven (DHO) and water bath (WB) on the impact strength (IS) and microhardness $(H V)$ of the conventional heat cure acrylic resin (CHCAR) and rubber reinforced heat cure acrylic resin (RRHCAR). Samples were fabricated using CHCAR (control Group A; $n=114$ ) and RRHCAR (experimental Group $B ; n=114$ ). Group $A$ and $B$ were further divided into subgroups according to processing techniques: $A C O, D H O$ and $W B(n=38$ each) for both testing variables microhardness and impact strength $(n=19$ each). Charpy testing machine and Vickers microhardness tester were utilized. Analysis of variance was applied to determine the presence of significant differences among processing techniques while P-value $\leq 0.05$ was considered as significant. Water bath (P-value $<0.001)$ and DHO technique (p-value <0.001) showed significant differences between both groups' impact strength and microhardness. Impact strength and microhardness were improved in RRHCAR compared to CHCAR processed by ACO and DHO and were less in samples processed by WB technique. The air circulating oven exhibited highest microhardness in both testing materials. Dry heat oven showed improved values of impact strength in conventional heat cure acrylic resin.
\end{abstract}

Keywords: dental polymers, dental prosthesis, prosthodontics, dentures, rubber reinforced acrylic, water bath

\section{Introduction}

Poly methyl meth acrylate (PMMA) is the most widely accepted materials for denture base applications [1-3] because of its low cost, easy manipulation and convenience in repair [4-6]. However poor mechanical properties (lower modulus of elasticity, brittleness) and a high coefficient of thermal expansion are the reasons of its failure in the clinical practice [7, 8]. For enhancement in its mechanical properties, researchers have amalgamated additives such as glass fibers, carbon fibers, rubber graft copolymer and polyethylene in its composition [3]. Along with additives, different types of equipment have also been used for processing of PMMA in an attempt to improve its strength, but none of them have been shown to be superior to the other [9-11]. To enhance the properties of strength. Commercially available rubber reinforced PMMA contain low molecular weight butadiene styrene rubber known [12]. The addition of rubber slows down the crack propagation and improve impact strength by absorbing greater amount of energy compared to other reinforced denture base materials [13]. Butadiene rubber can be introduced in the PMMA matrix up to $30 \%$ by weight without significantly effecting the viscosity $[14,15]$.

\footnotetext{
*email: drsohail_78@hotmail.com
} 
Hardness of denture base material exhibits the ease of finishing and its resistance to scratching during cleaning a denture [16]. Maintenance of removable denture requires cleaning with mechanical means such as denture cleaning brush that can cause scratches or abrasions. Low hardness value of acrylic denture base signifies that denture can easily be abraded and can create microcracks therefore weakening the denture base and encourage bacterial accumulation [17].

Processing environmental factors such as wet (water) or dry (air) influence the mechanical properties (such as hardness and strength) of the denture base. Ogawa et al. [17] reported in their study that the polymerization of resin dry conditions possess higher surface hardness compared to polymerizing resins in wet environment at similar temperatures. Moreover, polymerization technique plays a significant role in the influence of impact strength of the acrylic denture base resins [18]. Techniques for denture processing include water bath (WB), air circulating oven (ACO) and dry heat oven (DHO). WB is commonly used for denture base processing due to its ease of handling and cost effectiveness [11, 19, 20]. While DHO is also used for curing heat cure acrylic resin that showed improved dimensional stability, but less common due to its equipment cost and efficiency [21]. In addition, DHO has a slow heating rate and requiring a higher temperature compared to a WB [22]. An ACO is a relatively new equipment used for processing PMMA denture base materials [23]. Till date, there are no in-vitro experimental studies reporting the performance of ACO for processing and its effects on conventional heat cure acrylic resin. Therefore, the objective of the present study was to determine and compare the effects of different curing techniques on hardness and impact strength of rubber reinforced acrylic resin and conventional heat cure acrylic resin. The null hypothesis of the study was that there would be no effect on impact strength and microhardness of different processing techniques on conventional and rubber reinforced acrylic resin.

\section{Materials and methods}

The present experimental study was approved by the institutional ethical review board (Ref: IRB834/DUHS/2017/38). A total of two hundred and twenty-eight samples were fabricated from conventional heat cure acrylic resin (Meliodent, Heraeus Kulzer, Ltd, Berkshire, Germany) and rubber reinforced acrylic resin (Meadway Imperial high impact acrylic, Surrey, UK) (Table 1).

Table 1. The composition of acrylic resin materials used

\begin{tabular}{|c|c|c|c|}
\hline Material & Powder & Liquid & Manufacturer \\
\hline $\begin{array}{c}\text { Conventional heat cure } \\
\text { acrylic resin }\end{array}$ & Poly methyl methacrylate & $\begin{array}{c}\text { Methyl methacrylate, Di } \\
\text { methacrylate }\end{array}$ & $\begin{array}{c}\text { Meliodent, Heraeus Kulzer, Ltd, } \\
\text { Berkshire, Germany }\end{array}$ \\
\hline $\begin{array}{c}\text { Rubber reinforced } \\
\text { acrylic resin }\end{array}$ & $\begin{array}{c}\text { Copolymer of methyl } \\
\text { methacrylate and butadiene } \\
\text { styrene }\end{array}$ & $\begin{array}{c}\text { Methyl meth acrylate, } \\
\text { crosslinking agent. }\end{array}$ & $\begin{array}{c}\text { Meadway Imperial high impact acrylic, } \\
\text { Surrey, UK }\end{array}$ \\
\hline
\end{tabular}

Sample size ( $\mathrm{n}=228 ; 57 /$ testing variable) was calculated by using Pass version 11 with $95 \%$ of confidence interval and $80 \%$ power. There were two testing variables; impact strength (IS) and microhardness (HV) for samples processed by three different techniques including ACO, DHO, WB.

\subsection{Sample preparation}

The specimens for all testing materials were prepared using the prefabricated plastic sheets (PPS); dimensions $30 \mathrm{~mm} \times 10 \mathrm{~mm} \times 2.5 \mathrm{~mm}$ for microhardness and of $64 \mathrm{~mm} \times 10 \mathrm{~mm} \times 3 \mathrm{~mm}$ for impact strength testing (Figure 1a). Dental plaster was mixed with water according to manufacturer instructions and poured in the lower half of the metal flask (Med Fair instruments, Model\#AD-111, Sialkot, Pakistan). Five plastic sheets were placed in each flask over the plaster surface and allowed to set (Figure 1b) and painted with two successive coats of cold mould seal (CMS) separating medium (Figure 1c). After the material was set, the upper half of flask was mixed with dental plaster, placed over lower half and allowed to set. On complete setting, flasks were separated, PPS were removed, and second coat of CMS was applied. After achieving moulds of specific measurements, the RRHCAR and CHCAR were mixed 
according to manufacturers' recommendation and packed during the doughy stage into the moulds. These metal flasks were pressed under bench press for $15 \mathrm{~min}$ to flow excess material out from the flask (Figure 1d) which was removed with a sharp wax knife. All flasks were cured in three techniques as follow: ACO at $92^{\circ} \mathrm{C}$ for $120 \mathrm{~min}$ (Heraeus (GS/ DVE), Model \# JT 5050, Sr. \# 3201), DHO at $92^{\circ} \mathrm{C}$ for $120 \mathrm{~min}$ (Heraeus, and Model \# 0016, Hanau, Germany) and WB at $74^{\circ} \mathrm{C}$ for $90 \mathrm{~min}$ (Figure 1e) followed by terminal boiling of $100^{\circ} \mathrm{C}$ for $30 \mathrm{~min}$ (Model \# TC 502D).

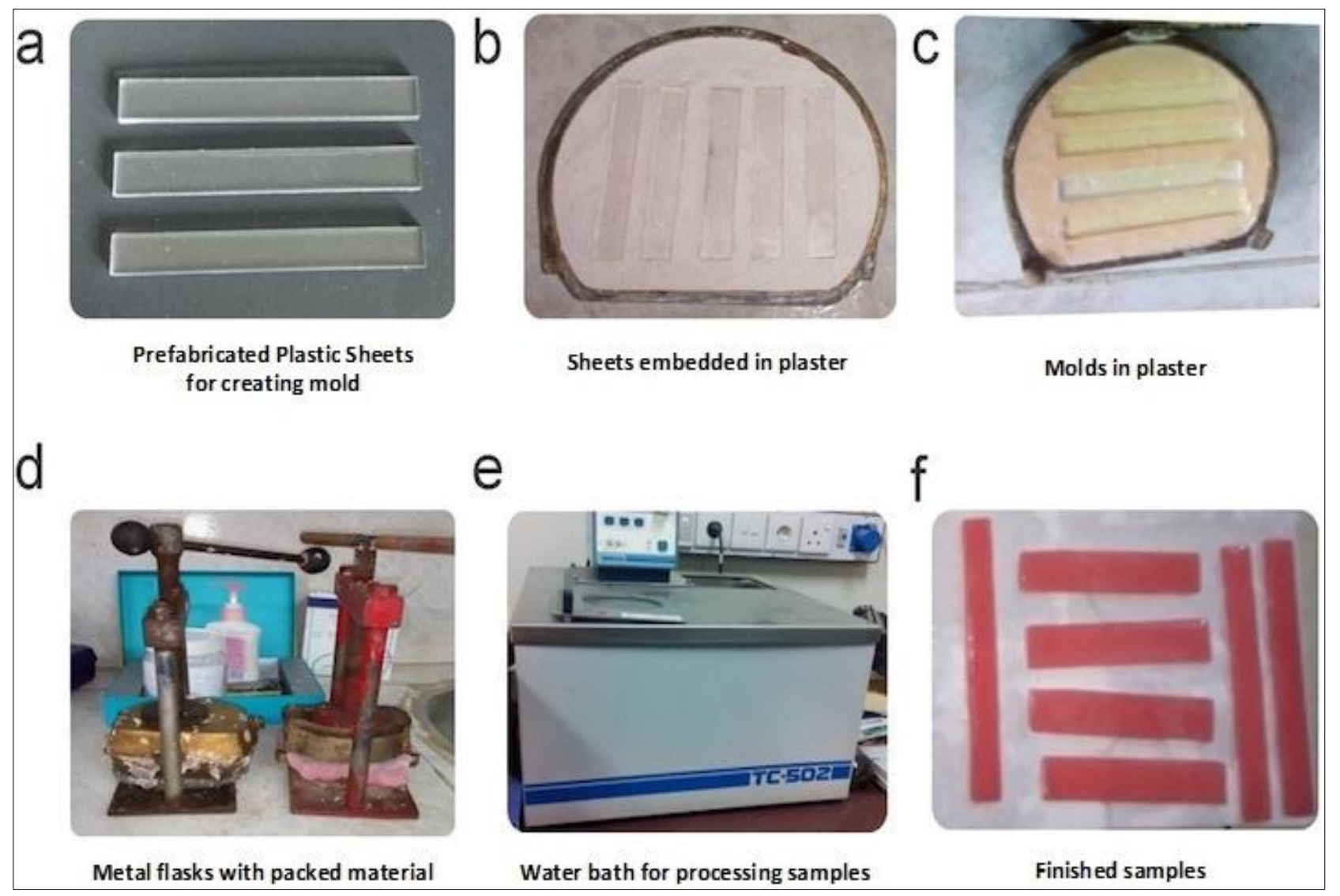

Figure 1. Stepwise presentation of specimen preparation for testing the impact strength and microhardness of resin based acrylic materials; (a) prefabricated plastic sheets used for fabricating specimens for testing microhardness $(30 \times 10 \times 2.5 \mathrm{~mm})$ and impact strength $(64 \times 10 \times 3)$; (b) dental plaster poured in the lower half of the metal flask; (c) five plastic sheets in place in each flask;

(c) prepared moulds after the application of separating medium; (d) acrylic resin denture base material packed in to the flasks under pressure for 15 min for packing and removal of excessive material;

(e) water bath for the heat curing cycle; (f) prepared specimens after finishing and polishing

Following the completion of curing process, specimens were removed from flask, followed by finishing and polishing with slurry pumice and cotton buff (Figure 1f). Dimensions of all samples were rechecked by vernier caliper (VIS, Poland) and visually inspected for any porosities before storing in covered labelled distilled water containers for 28 days at $37^{\circ} \mathrm{C}$. Conventional heat cure acrylic resin was taken as control (Group A), while rubber reinforced heat cure acrylic resin was taken as the experimental material (Group B). Each group contained 114 samples and further subdivided into 3 subgroups for three curing modes: WB $(n=38)$ coded as A1 and B1, by DHO $(n=38)$ coded as A2 and B2 and ACO ( $n=38)$ coded as A3 and B3. Each subgroup was subjected to two testing procedures i.e., HV $(n=19)$ and IS $(n=19)$. 


\subsection{Impact strength testing}

Impact strength was assessed by Charpy tester (Ceast-Resil impactor, Type 6967000, Serial\#18711 (Izod/Charpy, Italy). Each sample was clamped horizontally from both ends and were fractured by swinging pendulum struck in the center of the specimen. On fracture of specimen the scale readings determined the amount of energy absorbed by the specimen and impact energy (Joules). The Charpy's impact strength was calculated by the following equation [24]:

$$
\text { Impact strength }\left(\mathrm{KJM}^{-2}\right)=\mathrm{E} / \mathrm{TW}
$$

where: E stands for absorbed energy (KJ), W and T represents the width and thickness of the specimen respectively at the center.

\subsection{Microhardness testing}

Microhardness was tested using a digital Vickers microhardness tester (Indentec ZHV/Vickers microhardness tester, serial\# 073516, Ulm, Germany). Vickers hardness was used to evaluate the hardness number known as Vickers hardness number (VHN). Applied load ranged from 50-100 g for 10-15 s. For each sample Vickers hardness indentations were made at three different points on the specimen and the mean microhardness was calculated.

\subsection{Statistical analysis}

The data were statistically analyzed using SPSS version (v.21 IBM, USA). Analysis of variance (ANOVA) and the Scheffe multiple comparison post-hoc tests were applied to determine the presence of significant differences between processing techniques while P-value $\leq 0.05$ was considered as significant. Impact strength and microhardness data between control and experimental groups were assessed by applying t-test.

\section{Results and discussions}

In the current study it was reported that processing techniques has significantly influenced $(\mathrm{p}<0.001)$ the microhardness and impact strength of both conventional and rubber reinforced acrylic resin. Impact strength was reported higher for group B compared to the group A for each curing mode except water bath (WB). Impact strength was highest for group B specimens cured by dry heat oven $(11.85 \pm 0.90$ $\left.\mathrm{J} / \mathrm{m}^{2}\right)$ and air circulating oven $\left(11.54 \pm 0.46 \mathrm{~J} / \mathrm{m}^{2}\right)$. While group A showed the lowest value of strength $\left(6.46 \pm 0.31 \mathrm{~J} / \mathrm{m}^{2}\right)$ for dry heat oven curing (Table 2) however it was significantly higher for the specimens cured by air circulating oven $\left(11.26 \pm 0.74 \mathrm{~J} / \mathrm{m}^{2}\right)$. Microhardness was reported lower for group B compared to group A except for air circulating oven (Table 2). The highest microhardness was observed in case of air circulating oven without any significant differences $(p=0.102)$ between the control $(15.42 \pm 1.74 \mathrm{VHN})$ and experimental group $(16.84 \pm 0.77 \mathrm{VHN})$.

Table 2. Effect of various processing techniques on impact strength and microhardness of control and the experimental group specimens

\begin{tabular}{|c|c|c|c|c|c|c|}
\hline & \multicolumn{3}{|c|}{ Impact strength $\left(\mathbf{J}^{\prime} \mathbf{m}^{\mathbf{2}}\right)$} & \multicolumn{3}{c|}{ Microhardness (VHN) } \\
\cline { 2 - 7 } & $\begin{array}{c}\text { Control } \\
\text { (Group A) }\end{array}$ & $\begin{array}{c}\text { Experimental } \\
\text { (Group B) }\end{array}$ & P-value & $\begin{array}{c}\text { Control } \\
(\text { Group A) }\end{array}$ & $\begin{array}{c}\text { Experimental } \\
(\text { Group B) }\end{array}$ & P-value \\
\hline Water bath & $6.8 \pm 0.55$ & $4.67 \pm 1.09$ & $<0.001$ & $13.42 \pm 1.68$ & $9.00 \pm 0.67$ & $<0.001$ \\
\hline Dry heat oven & $6.46 \pm 0.31$ & $11.85 \pm 0.90$ & $<0.001$ & $15.15 \pm 1.21$ & $12.43 \pm 2.05$ & $<0.001$ \\
\hline Air circulating oven & $11.26 \pm 0.74$ & $11.54 \pm 0.46$ & 0.169 & $15.42 \pm 1.74$ & $16.84 \pm 0.77$ & 0.102 \\
\hline
\end{tabular}

p-value $\leq 0.05$ was considered as significant

Table 3 presents the intra-group comparison through Scheffe multiple comparison post-hoc test. In terms of impact strength and microhardness of group A, ACO showed significant differences comparing water bath with air circulating oven. However, there was no significant difference while comparing water 
bath with air circulating oven. In the experimental group, both DHO and ACO showed a significant difference in the impact strength compared to water bath.

Table 3. Scheffe multiple comparisons post hoc test on impact strength and microhardness

\begin{tabular}{|c|c|c|c|c|c|}
\hline & Study group & WB & DHO & $\mathrm{ACO}$ & Mean Difference \\
\hline \multirow[t]{6}{*}{ Impact strength } & \multirow{3}{*}{$\begin{array}{l}\text { Control group } \\
\text { (Group A) }\end{array}$} & 6.799 & 6.464 & & 0.33553 \\
\hline & & 6.799 & & 11.261 & $4.79632^{\mathrm{a}}$ \\
\hline & & & 6.464 & 11.261 & $4.46079^{\mathrm{b}}$ \\
\hline & \multirow{3}{*}{$\begin{array}{c}\text { Experimental group } \\
\text { (Group B) }\end{array}$} & 4.669 & 11.853 & & $-7.18368^{c}$ \\
\hline & & 4.669 & & 11.541 & $-6.87158^{d}$ \\
\hline & & & 11.853 & 11.541 & 0.31211 \\
\hline \multirow[t]{6}{*}{ Microhardness } & \multirow{3}{*}{$\begin{array}{l}\text { Control group } \\
\text { (Group A) }\end{array}$} & 13.421 & 15.147 & & $1.72579^{\mathrm{e}}$ \\
\hline & & 13.421 & & 15.421 & $2.00000^{f}$ \\
\hline & & & 15.147 & 15.421 & 0.27421 \\
\hline & \multirow{3}{*}{$\begin{array}{l}\text { Experimental group } \\
\text { (Group B) }\end{array}$} & 9.000 & 12.434 & & $-3.43421^{\mathrm{g}}$ \\
\hline & & 9.000 & & 16.842 & $-7.84211^{\mathrm{h}}$ \\
\hline & & & 12.434 & 16.842 & -4.40789 \\
\hline
\end{tabular}

a) significant difference on comparing water bath with air circulating oven; b) dry heat oven with air circulating oven showed significant difference of values; c) indicates significant difference on comparing water bath with dry heat oven; d) water bath with air circulating oven showed significant difference of values; e) significant difference for microhardness water bath with dry oven; f) water bath with air circulating oven showed significant difference of values; g) significant difference for microhardness water bath with dry oven; h) water bath with air circulating oven showing a significant difference.

The aim of this study was to exhibit the effect of different processing techniques on impact strength and microhardness of conventional and rubber reinforced acrylic resin. The data from the current study rejects the null hypothesis. The result obtained in control group where samples of conventional heat cure acrylic showed highest mean value cured through air circulating oven $\left(92^{\circ} \mathrm{C}\right.$ for $\left.120 \mathrm{~min}\right)$ than water bath cured samples $\left(74^{\circ} \mathrm{C}\right.$ for $90 \mathrm{~min}$ and then $100^{\circ} \mathrm{C}$ for $\left.30 \mathrm{~min}\right)$ followed by samples cured in dry oven (Table 2). In experimental group that was fabricated by rubber reinforced acrylic resin showed highest impact strength and statistically significant results, when cured by dry heat oven and compared with water bath curing technique. Urban et al. [25] evaluated residual monomer content of reline acrylic resins by water bath and microwave curing techniques. The authors reported that microwave curing reduced the residual monomer content since the specimens of heat cure acrylic resin were cured in dry state. Therefore, possible causes of reduced monomer content could be vaporization of monomer in a dry environment of microwave oven and the constant heat generated during polymerization inside oven chamber throughout the processing.

Rubber incorporation in high impact heat cure resin is in the form of acrylate terminated butadiene styrene block copolymer. It is responsible to cause dispersion of small cracks in the matrix on sudden blow and absorb large amount of energy which prevents a large crack which in turn manifest high impact strength of a material [26]. Shenoy et al. [27] used two conventional and two high impact heat cure acrylic resin in their study to evaluate impact and flexural strength among these two acrylic resin denture base materials. They concluded that super unbreakable heat cure denture base had four times higher impact strength than conventional heat cure acrylic resin which is also evident in the current study. The results show high impact strength because of rubber incorporation and is highly recommended for patients having history of denture fracture. Murphy et al [28] in an in vitro study investigated impact strength of three denture base materials (conventional heat cure acrylic, rubber reinforced heat cure acrylic and injection molded heat cure acrylic) and reported better impact strength in rubber reinforced 
acrylic resin because of the presence of rubber particles. These results are in agreement to the findings of the current study i.e. rubber reinforced heat cure acrylic (high impact) showed improved impact strength.

Microhardness showed highest values in the samples of conventional heat cure acrylic cured by air circulating oven at $92^{\circ} \mathrm{C}$ for $120 \mathrm{~min}$, followed by dry oven cured at $92^{\circ} \mathrm{C}$ for $120 \mathrm{~min}$ and lowest value was found among samples cured by water bath at $74^{\circ} \mathrm{C}$ for $90 \mathrm{~min}$ and then $100^{\circ} \mathrm{C}$ for $30 \mathrm{~min}$. In our study, air circulating oven cured samples showed better/lesser effects on microhardness regardless of material tested. It is assumed that acrylic processing in a dry atmosphere such as microwave oven do not allow water uptake by acrylic, as well as inhibits process of diffusion and hydrolysis [29]. This phenomenon has provided some clue to understand enhanced value of VHN when the samples were cured in dry atmosphere. High value of surface microhardness of acrylic resin revealed its high abrasion resistance which effects the longevity and fracture resistance of a denture [30]. To validate this assumption, there is need of further investigations.

Gungor et al. [2] evaluated flexural strength and microhardness of two commercially available heat cure acrylic resin cured through water bath followed by 12 groups of different curing cycles. Results of their study showed that samples that were heat cured $\left(74^{\circ} \mathrm{C}\right.$ for $9 \mathrm{~h}$ followed by boiling at $100^{\circ} \mathrm{C}$ for half an hour) showed the highest microhardness values in both materials. The authors concluded that different curing cycles affects microhardness of the material. The authors reported that microhardness increase at higher curing temperature which in accordance with the current study. In our research, variation in temperature and time influenced on microhardness and showed better values in samples that were cured in air circulating oven at $92^{\circ} \mathrm{C}$ for 120 min that was increased from water bath. This increase in microhardness may be due to variation in time and temperature which has influenced on residual monomer content of the samples.

The phenomenon of decreased water sorption could also be considered as a possible cause of increased hardness among samples cured at increased temperature. High temperature causes decrease in water sorption and enhances hardness of acrylic resin. Low temperature curing causes increased water sorption as it allows water to entrap in between intermolecular chains and effects on its hardness [31, 32]. Although the findings of the present in vitro study controlled various factors during the sample fabrication and simulated the oral environment, further in-vivo and clinical studies are essential to validate the findings.

\section{Conclusions}

The present study revealed that processing techniques influences differently on conventional and rubber reinforced acrylic resin. Rubber reinforced heat cure acrylic resin exhibited higher microhardness and impact strength than the conventional heat cured resin. It can preferably be recommended for the patients who have repeated history of denture fracture on dropping accidently or due to any neuromuscular disorder. Air circulating oven can be used as an alternative processing equipment for the fabrication of heat cure acrylic dentures as it showed better impact strength and microhardness. However, further studies are required to validate the findings of the present study in the simulated and clinical implications.

\section{References}

1.NISAR, S., MOEEN, F., HASAN, U., Effect of varying curing regimes and powder-liquid ratios on the flexural strength and surface porosities of heat cure acrylic: an in-vitro experiment, Int. J. Dent. Sci. Res., 3(3), 2015, 64-71.

2.GUNGOR, H., GUNDOGDU, M., ALKURT, M., DUYMUS, Z.Y., Effect of polymerization cycles on flexural strengths and microhardness of different denture base materials, Dent. Mater. J., 2017, 20162023.

3.ZAFAR, M.S., Prosthodontic applications of polymethyl methacrylate (PMMA): An update, Polymers, 12(10), 2020, 2299. 
4.ZAFAR, M.S., AHMED, N., Nanoindentation and surface roughness profilometry of poly methyl methacrylate denture base materials, Technol. Health. Care., 22(4), 2014, 573-581

5.HASSAN, M., ASGHAR, M., DIN, S.U., ZAFAR, M.S. 2019. Chapter 8 - Thermoset polymethacrylate-based materials for dental applications. 273-308.

6.NAJI, S.A., BEHROOZIBAKHSH, M., HAJIZAMANI, H., HABIBZADEH, S., Recent advances and future perspectives for reinforcement of poly (methyl methacrylate) denture base materials: a literature review, J. Dent. Biomater., 5(1), 2018, 490-502.

7.SAKAGUCHI, R.L., POWERS, J.M., 2012. Craig's restorative dental materials. Elsevier/Mosby, Philadelphia, PA.

8.UCAR, Y., AKOVA, T., AYSAN, I., Mechanical properties of polyamide versus different PMMA denture base materials, J. Prosthodont. Implant. Esthetic. Reconst. Dent., 21(3), 2012, 173-176.

9.ABDULWAHHAB, S.S., ALNAKKASH, W.A., The effect of autoclave processing on some properties of heat cured denture base material, J Baghdad. Coll. Dent., 24(3), 2012, 13-17.

10.JADHAV, R., BHIDE, S.V., PRABHUDESAI, P.S., Assessment of the impact strength of the denture base resin polymerized by various processing techniques, Indian. J. Dent. Res., 24(1), 2013, 19-25.

11.KAREEM, A.E., Strength and surface roughness of cross linking acrylic resin processed by different heat curing methods, Iraqi. Dent. J., 37(1), 2015, 13-19.

12.JAGGER, D., JAGGER, R., ALLEN, S., HARRISON, A., An investigation into the transverse and impact strength of high strength denture base acrylic resins, J. Oral. Rehabil., 29(3), 2002, 263-267.

13.RICKMAN, L.J., PADIPATVUTHIKUL, P., SATTERTHWAITE, J.D., Contemporary denture base resins: Part 1, Dent. Update, 39(1), 2012, 25-30.

14.BAKR, T.O., AMEEN, R.M., Evaluation of some properties of heat curing denture base materials cured by different curing techniques, Zanco. J. Med. Sci., 21(2), 2017, 1796-1806.

15.KOSTIC, M., PEJCIC, A., IGIC, M., GLIGORIJEVIC, N., Adverse reactions to denture resin materials, Eur. Rev. Med. Pharmacol. Sci., 21(23), 2017, 5298-5305.

16.MACHADO, A.L., BREEDING, L.C., VERGANI, C.E., DA CRUZ PEREZ, LUCIANO ELIAS., Hardness and surface roughness of reline and denture base acrylic resins after repeated disinfection procedures, J. Prosthet. Dent., 102(2), 2009, 115-122.

17.OGAWA, T., HASEGAWA, A., Effect of curing environment on mechanical properties and polymerizing behaviour of methyl-methacrylate autopolymerizing resin, J. Oral. Rehabil., 32(3), 2005, 221-226.

18.SADAMORI, S., GANEFIYANTI, T., HAMADA, T., ARIMA, T., Influence of thickness and location on the residual monomer content of denture base cured by three processing methods, J. Prosthet. Dent, 72(1), 1994, 19-22.

19.GAD, M.M., FOUDA, S.M., ARREJAIE, A.S., AL-THOBITY, A.M., Comparative effect of different polymerization techniques on the flexural and surface properties of acrylic denture bases, $J$. Prosthodont., 28(4), 2019, 458-465.

20.BURAL, C., AKTAŞ, E., DENIZ, G., ÜNLÜÇERÇI, Y., BAYRAKTAR, G., Effect of leaching residual methyl methacrylate concentrations on in vitro cytotoxicity of heat polymerized denture base acrylic resin processed with different polymerization cycles, J. Appl. Oral. Sci., 19(4), 2011, 306-312.

21.WONG, D.M., CHENG, L.Y., CHOW, T., CLARK, R.K., Effect of processing method on the dimensional accuracy and water sorption of acrylic resin dentures, J. Prosthet. Dent., 81(3), 1999, 300304.

22.PEYTON, F.A., Packing and processing denture base resins, J. Am. Dent. Assoc, 40(5), 1950, 520 528.

23.BONUSO, J.L., SWAYNE, S.M., Dual fan convection oven, United States patent US 8,258,435. 2012.

24.AHMAD, A.S., Denture cleanser's effect on impact strength of heat cured acrylic, Iraqi. Dent. J., 37(1), 2015. 
25.URBAN, V.M., MACHADO, A.L., OLIVEIRA, R.V., VERGANI, C.E., PAVARINA, A.C., CASS, Q.B., Residual monomer of reline acrylic resins: effect of water-bath and microwave postpolymerization treatments, Dent. Mater., 23(3), 2007, 363-368.

26.JAGGER, D., HARRISON, A., JANDT, K., The reinforcement of dentures, J. Oral. Rehabil., 26(3), 1999, 185-194.

27.SHENOY, D., UMA, K., MATHEW, K., REDDY, P.S., JAIN, A.R., ANJANEYULU, K., Evaluation of impact and flexural strength of conventional heat cure polymethyl methacrylate resin and high impact, Biol. Med., 9(2), 2017, 1-4.

28.MURPHY, W.M., BATES, J.F., HUGGETT, R., BRIGHT, R., A comparative study of 3 denture base materials, Br. Dent. J., 152(8), 1982, 273-276.

29.AZZARRI, M., CORTIZO, M., ALESSANDRINI, J., Effect of the curing conditions on the properties of an acrylic denture base resin microwave-polymerised, J. Dent., 31(7), 2003, 463-468.

30.AYAZ, E.A., DURKAN, R., KOROGLU, A., BAGIS, B., Comparative effect of different polymerization techniques on residual monomer and hardness properties of PMMA-based denture resins, J Appl. Biomater. Funct. Mater., 12(3), 2014, 228-233.

31.STAFFORD, G., BATES, J., HUGGETT, R., HANDLEY, R., A review of the properties of some denture base polymers, J. Dent., 8(4), 1980, 292-306.

32.CHAIYASAT, P., NAMWONG, S., OKUBO, M., CHAIYASAT, A., Synthesis of micrometer-sized poly (methyl methacrylate) particles by microsuspension iodine transfer polymerization (ms ITP), $R S C$. Adv., 6(97), 2016, 95062-95066.

$\overline{\text { Manuscript received: } 30.04 .2021}$ 